\title{
Biology of a deep-water sea anemone (Anthozoa: Actiniidae) from eastern Canada: spawning, development, and growth
}

\author{
Annie Mercier ${ }^{\mathrm{a}}$, Sandrine Baillon ${ }^{\mathrm{a}}$, Marymegan Daly ${ }^{\mathrm{b}}$, Jason Macrander $^{\mathrm{b}}$, \\ and Jean-François Hamel ${ }^{\mathrm{c}}$
}

${ }^{a}$ Department of Ocean Sciences (OSC), Memorial University, St. John's (Newfoundland)

Canada A1C 5S7, Email: amercier@mun.ca

${ }^{\mathrm{b}}$ Evolution, Ecology, and Organismal Biology, The Ohio State University, 300 Aronoff Hall, 318 W 12th Avenue, Columbus, OH 43210-1293, USA, Emails: MD: daly.66@osu.edu, JM: macrander.1@osu.edu

${ }^{\mathrm{c}}$ Society for the Exploration and Valuing of the Environment (SEVE), Portugal Cove-St. Philips (Newfoundland) Canada A1M 2B7, Email: jfhamel.seve@gmail.com

Key words: Broadcast spawning, embryos, larvae, bathyal, deep sea, cnidarians

Short title: Life history of a deep-sea anemone 


\section{Abstract}

Knowledge of the general biology and reproductive ecology of deep-water species can

3 help predict their resilience to environmental and anthropogenic disturbances. The present study

4 centers on live specimens of a deep-water sea anemone which were collected at bathyal depths

5 between 1100 and $1400 \mathrm{~m}$ and kept in a mesocosm for over 6 years. Morphology and DNA

6 sequencing confirmed that the species belongs to the genus Urticina. Male and female $(9-10 \mathrm{~cm}$

7 pedal disk diameter, 90 tentacles) spawned 4 years post collection, in early spring (March). Both

8 sexes released gametes through the mouth. The negatively buoyant oocytes $(550-600 \mu \mathrm{m}$ in

9 diameter) quickly settled on the rocks and soft sediments surrounding the female. Lecithotrophic

10 embryonic and larval development occurred on the substratum. Fully developed planula larvae

11 were detected after 17-21 days. Planulae started to crawl and swim around but remained

12 demersal. Metamorphosis and settlement occurred after 30-35 days, exclusively on hard

13 substrata and preferentially on undersurfaces. Offspring grew slowly, developing 8 tentacles

14 after 5 months and 24 tentacles after 12 months (3-4 mm pedal disk diameter). After 2.5 years of

15 growth, the captive-born sea anemones reached $12-16 \mathrm{~mm}$ in pedal disk diameter and possessed

$16 \quad 48-54$ tentacles.

\section{1. Introduction}

Pelagic and benthic members of phylum Cnidaria have successfully colonized freshwater

19 and saltwater environments all around the world (Rogers, 2009). They are particularly diversified

20 and abundant in marine habitats, from coastal shores down to the deepest oceanic trenches.

21 Studies of deep-sea cnidarians, including aspects of their distribution and biology, have largely 
22 focused on corals (Cairns, 1982, 2007; Watling et al., 2011; Young, 2003) due to the fact that

23 they create complex tri-dimensional habitats and play major roles in ecosystem functioning

24 (Baillon et al., 2012; Buhl-Mortensen and Mortensen, 2005; Cerrano et al., 2010; Roberts et al.,

25 2006). This focal interest has deflected attention from other very abundant cnidarians of the

26 deep, including members of order Actiniaria (sea anemones). Sea anemones are reportedly

27 abundant on rocky bottoms of bathyal and abyssal zones, and around hydrothermal vents (Aldred

28 et al., 1979; Rodríguez and Daly, 2010); as an example, Aldred et al. (1979) indicated that the

29 sea anemone Actinoscyphia aurelia could reach densities of up to $6 \mathrm{ind}^{-2}$ at depths between

30500 and $2000 \mathrm{~m}$ in the Northeast Atlantic.

31 Despite their abundance, deep-water sea anemones remain poorly studied, and the topic

32 of a limited number of ecological or biological investigations (details below). From samples

33 collected at bathyal depths in the Southern Ocean, the externally brooding Epiactis georgiana

34 was determined to exhibit superfetation (several cohorts of offspring developing simultaneously)

35 and seasonal release of embryos/larvae in the austral spring (Rodríguez et al., 2013). Van Praët

36 and Duchateau (1984) and Van Praët (1990) revealed the existence of reproductive seasonality in

37 correlation with the flux of organic matter at $2000 \mathrm{~m}$ in the sea anemone Paracalliactis

38 stephensoni from the Bay of Biscay. Similarly, seasonal patterns of spawning in Phelliactis

39 hertwigi and P. robusta from bathyal depths in the Porcupine Seabight (northeast Atlantic) were

40 described by Van Praët et al. (1990), whereas Bronsdon et al. (1993) reported that Amphianthus

41 inornata released gametes in the spring in the Porcupine Abyssal Plain (PAP). The sea anemone

42 Allantactis parasitica, which lives on deep-sea gastropods in the Northwest Atlantic spawned

43 twice a year in the laboratory, during the spring and fall peaks of phytodetritus abundance

44 (Mercier and Hamel, 2009a). A few species were found not to display any detectable seasonal 
45 breeding, including the sea anemone Kadosactis commensalis, living as commensal on

46 holothurians in the PAP (Bronsdon et al., 1993), and two carpet anemones (order Zoanthidae)

47 associated with hermit crabs, Epizoanthus paguriphilus (770-1065 m) and E. abyssorum (3749-

$484400 \mathrm{~m}$ ) (Muirhead et al., 1986).

49 It is expected that most deep-water species will exhibit slow growth and great longevity

50 (Gage and Tyler, 1991) compared with shallow-water counterparts, although data on growth

51 rates of deep-sea cnidarians are scarce. Current knowledge is mostly centered on banding

52 patterns and/or radiometric analysis of skeletal elements in corals (e.g. Andrews et al., 2002;

53 Hamel et al., 2010; Mortensen and Rapp, 1998; Risk et al., 2002; Roark et al., 2009; Sherwood

54 and Edinger, 2009). While these techniques cannot be used in sea anemones due to the absence

55 of a hard skeleton, growth can also be estimated from the study of live specimens in the

56 laboratory (Cordes et al., 2001; Hamel et al., 2010; Orejas et al., 2011) or in nature (Brooke and

57 Young, 2009). To our knowledge, the only data available for deep-water actiniarians were

58 provided by Mercier and Hamel (2009a), who estimated that the sea anemone A. parasitica

59 required 6-11 years to reach its maximum size, based on the growth of newly-settled juveniles to

6015 months.

61 Sea anemones are ubiquitous in deep waters of the Northwest Atlantic. In some locations

62 of the rocky continental slope of Newfoundland and Labrador (eastern Canada), densities

63 between 5 and 9 ind $\mathrm{m}^{-2}$ have been recorded (DFO, unpublished data). Genera whose members

64 are commonly collected as trawl bycatch include Urticina, Bolocera, Hormathia, and

65 Actinostola. Among these, individuals of the genus Urticina are the most frequently encountered.

66 A wide range of life styles and reproductive habits have been reported so far in shallow-water

67 species of this genus, reflecting both significant diversity within the group and raising questions 
68 about its taxonomy (Fautin et al., 2005). Genetic studies (e.g. Solé-Cava et al., 1985; 1994) have

69 failed to find differences among the North Atlantic species, but the circumscription of new

70 species from within the previously global Urticina crassicornis, U. eques, and U. felina (Hand,

71 1955; Hauswaldt, 1999; Sanamyan and Sanamyan, 2006) have refined and limited the

72 circumscription of the North Atlantic species.

73 Urticina (=Tealia) crassicornis was initially reported as a broadcast-spawner in Europe

74 (Appellöf, 1900) and defined as a brooder on the west coast of the USA (Hand, 1955). Chia and

75 Spaulding (1972) later confirmed that $U$. crassicornis in northwestern USA fits the description of

76 Appellöf (1900), whereas it is viviparous in the Barents Sea (Kaliszewicz et al., 2012). Most

77 species described so far exhibit seasonal breeding. Individuals of $U$. lofotensis along the coast of

78 California (USA) were shown to reach full maturity and spawn at the end of December (Wedi

79 and Fautin Dunn, 1983). Studies of the reproduction of U. felina off the coast of Newfoundland

80 (eastern Canada) revealed that planulation peaked in August and that internal brooding could

81 lead to chimerism (Mercier et al., 2011b; Sun et al., 2012). Larson et al. (2012) reported seasonal

82 external brooding in the similar-looking, co-occurring species $U$. fecunda.

83 Limited knowledge is currently available on deep-water sea anemones and, to our

84 knowledge, nothing is known of the biology of Urticina species that are common at bathyal

85 depths. The purpose of the present work was to gain a better understanding of spawning, gamete

86 behaviour, development, and growth of a deep-water sea anemone of the genus Urticina

87 commonly collected along the continental slope of eastern Canada. Findings shed light on the

88 traits and adaptations that make this species successful in heavily fished deep waters. 


\section{Materials and Methods}

\subsection{Collection and maintenance}

91 Animals were obtained as bycatch from routine research surveys conducted by Fisheries

92 and Oceans Canada (DFO) in December 2009 with the CCGS Teleost along the continental slope

93 off Labrador $\left(56^{\circ} 26^{\prime} \mathrm{N}, 57^{\circ} 36^{\prime} \mathrm{W}\right)$, at depths ranging between 1100 and $1400 \mathrm{~m}$. Surveys

94 followed a stratified random sampling design with a Campellen 1800 trawl towed for 15 minutes

95 on $\sim 1.4 \mathrm{~km}$ of seafloor (gear opened and closed at depth). A total of 7 large sea anemones (9-10

$96 \mathrm{~cm}$ pedal disk diameter, $\sim 90$ tentacles), assumed to be of the same species based on morphology,

97 were collected and kept onboard the ship in a large flow-through tank (5000 L). Live specimens

98 were brought back to the laboratory, where they were kept in a mesocosm, consisting of a 600-L

99 tank supplied with running ambient seawater $\left(\sim 300 \mathrm{~L} \mathrm{~h}^{-1}\right)$ under darkened conditions.

100 Temperature in the tank ranged annually between -1 and $8^{\circ} \mathrm{C}$, according to a temperature-light

101 logger HOBO Pendant (UA-002-64). A chilling unit (Universal Marine Industries, 5 hp) was

102 used for in-line cooling of seawater when ambient coastal temperatures were higher than those

103 characteristic of the bathyal environment in eastern Canada (DFO, 2009). The bottom of the tank

104 was filled with $15 \mathrm{~cm}$ of fine mud and scattered with a few boulders $(15-20 \mathrm{~cm}$ in diameter $)$ and

105 deep-water coral skeletons to mimic the natural habitat. Sea anemones were fed periodically,

106 generally once a month, either with complete live sea urchins (Strongylocentrotus pallidus),

107 frozen deep-sea shrimps (Eualus, Pandalus, Spirontocaris) or shucked mussels (Mytilus sp.).

\subsection{Taxonomic characterisation, DNA extraction and sequencing}

Small tissue samples were taken from the pedal disk of three of the seven specimens 110 collected and preserved in $100 \%$ ethanol. Total genomic DNA was extracted from the samples 
111 with the DNeasy kit (QIAGEN). Using previously published primers (Supplementary Table 1),

112 Template DNA, and illustra puReTaq Ready-To-Go PCR Beads the 12S, 16S, 18S, and partial

$11328 \mathrm{~S}$ ribosomal genes were amplified following the thermalcycler profile: 4 min at $94^{\circ} \mathrm{C}, 30$

114 cycles of $15 \mathrm{sec}$ at $94^{\circ} \mathrm{C}, 1 \mathrm{~min}$ at $52^{\circ} \mathrm{C}, 1 \mathrm{~min}$ at $72^{\circ} \mathrm{C}$, and $10 \mathrm{~min}$ at $72^{\circ} \mathrm{C}$ for the final

115 extension step. PCR products were sequenced on the Applied Biosystems 3730xl DNA Analyzer

116 by staff at Beckman Coulter Genomics (Danvers, MA). The forward and reverse sequences were

117 assembled in the program Geneious version 7.1.7 (Kearse et al., 2012) and compared against the

118 nucleotide database in GenBank (using BLAST searches) to determine whether the targeted loci

119 were sequenced. The new sequences for Urticina sp. and U. felina have been deposited in

120 Genbank (KT265262-KT265273). For our phylogenetic inference the newly acquired sequences

121 of $12 \mathrm{~S}, 16 \mathrm{~S}, 18 \mathrm{~S}$, and $28 \mathrm{~S}$ ribosomal genes were used in combination with previously

122 characterized sequences (Daly et al., 2008; Rodríguez et al., 2014). For each ribosomal gene, the

123 DNA sequences were aligned separately in MAFFT v7.017 (Katoh et al., 2002) using the search

124 strategy L-INS-I and default parameters (scoring matrix: 200PAM/k=2; Gap opening penalty:

125 1.53; Offset value: 0.123). The concatenated alignments were then subjected to maximum

126 likelihood analyses in RAxML v.7.2.8 (Stamatakis, 2006) using the GTR $+\Gamma$ option and allowing

127 for the $\alpha$ parameter to be estimated for each marker independently. Clade support was

128 determined using 1,000 bootstrap replicates (Fig. 1).

129 A whole specimen of Urticina sp. was deposited at the Canadian Museum of Nature

130 (Ottawa, Canada) under the reference number CMNI 2015-0012.

\section{$131 \quad 2.3$ Spawning and development}

The mesocosm holding the sea anemones was monitored daily, and sometimes more

133 often. When noted, the release/presence of gametes, including fertilized eggs (based on elevation 
134 of the fertilization envelope) was documented. Propagules were regularly sampled to assess

135 morphological changes and establish the development kinetic: once every hour during the first

136 day, then roughly every day up to the planula stage, and once a week following settlement. A

137 minimum of 10-15 individuals were examined on each occasion. They were described

138 morphologically and photographed using a stereomicroscope (Nikon SMZ 1500) or a

139 microscope (Nikon Eclipse 80i) coupled to a Nikon DXM1200F digital camera. Measures (either

140 Feret diameter or maximum length of the elongated propagules) were taken using Simple PCI

141 Imaging System ${ }^{\circledR}$. A new stage of development was considered attained when $\sim 50 \%$ of the

142 individuals reached it.

143 Most of the fertilized eggs $(\sim 80 \%)$ were left in the mesocosm with the parents and the

144 remaining propagules were transferred to 20 - $\mathrm{L}$ flow-through culture vessels $\left(\sim 40 \mathrm{~L} \mathrm{~h}^{-1}\right)$ under

145 similar environmental conditions. When propagules reached the planula larva stage, they were

146 tested for substrate preference among the following: glass (microscope slide), plastic (tank

147 bottom/walls), mud (0.2-5.0 nm particle diameter) and small rocks $(3-5 \mathrm{~cm})$. The larvae were

148 exposed to a single substrate at a time (apart from the tank material itself).

\section{$149 \quad 2.4$ Growth}

The growth of 6 juveniles that had settled naturally on small rocks was monitored for 2

151 years. Measurements were taken every 30-60 days of the pedal disk diameter, the column height,

152 and the number of tentacles. No food was provided to post-settled sea anemones apart from the

153 natural occurrence of inorganic and organic particles and live plankton (including phytoplankton,

154 copepods, and invertebrate larvae) present in the running seawater supply. Feeding of the 155 juveniles on crustaceans (copepods) was confirmed visually. 
Estimates of the age at full size were made using curve fitting with various models (e.g.

157 linear or exponential growth, exponential rise to a maximum). Growth estimates were obtained

158 from increments in pedal disk diameter measured in juveniles of Urticina sp., similar to the 159 method used previously for sea anemones (Mercier and Hamel, 2009a) and other cnidarians

160 (Cordes et al., 2001).

\section{3. Results and Discussion}

\section{$162 \quad 3.1$ Species identification, habitat and density}

The sea anemones under study were confirmed to belong to the genus Urticina, but did

164 not fit the description of any known species of the genus, which are notoriously difficult to

165 identify. The specimen examined for this description measured $9-10 \mathrm{~cm}$ in disk diameter and 10-

$16611 \mathrm{~cm}$ in column height (when fully deployed) and possessed $\sim 90$ tentacles $(7-9 \mathrm{~cm}$ long). The

167 column is stout and cylindrical, without verrucae, and the whole individual including tentacles,

168 oral disk and column is uniformly light pink in colour (Fig. 2). Darker pink lines run from the

169 mouth to edge of the oral disk, between the tentacles.

170 The phylogenetic analysis placed both Urticina sp. specimens together; with high

171 bootstrap support values supporting their position alongside the shallow-water Urticina felina

172 and Urticina coriacea (Fig. 1). In phylogenetic tree, the species of Urticina, including the one

173 under study, group together with strong support, but their affinity to other species or groups of

174 species is unclear because the internal nodes in the tree are all short and lack support. However,

175 the Urticina clade is not closely allied to the clade that includes the other deep-water species

176 (Bolocera and Liponema), highlighting that the deep-water sea anemone fauna is diverse in terms

177 of its evolutionary affiliations. 
179 occupying different depth strata, they exhibit different life styles and reproductive modes. In 180 eastern Canada, U. felina broods its offspring to the planula stage, before releasing them in the 181 water column (Mercier et al., 2011b), whereas Urticina sp. studied here is a broadcast spawner 182 (details below). Attachment of the pedal disk can be used to distinguish live individuals: in 183 Urticina sp., the pedal disk is the same diameter as the column (Fig. 2A), whereas in U. felina 184 the pedal disk swells to form a larger base. In addition, the uniform light pink colour of Urticina 185 sp. differs from the more patterned pigmentation exhibited by other Urticina species in eastern 186 Canada (personal observations). Finally, the tentacle tips of Urticina felina are generally thinner 187 and more pointed than those of Urticina sp., which are blunted.

188 Urticina sp. is a large sea anemone found exclusively on hard substrates (Fig. 2), 189 including rocks and coarse gravel, like most species of the genus Urticina (Chia and Spaulding, 190 1972; Larson et al., 2012; Sun et al., 2012). Some of the specimens collected were still attached 191 to small boulders (up to $15 \mathrm{~cm}$ in diameter) and occasionally to pieces of wood. Urticina sp. was 192 absent from trawls conducted on muddy or sandy bottoms. In the mesocosm, which had both 193 mud and rocks, Urticina sp. was almost always found attached to the latter and, occasionally, to 194 the glass walls. Based on 23 research trawls conducted in November-December 2013, between 19578 to 1782 individuals per trawl were counted, representing densities of 0.04 to 0.94 ind $\mathrm{m}^{-2}$ 196 (unpublished data). However, trawling is not an efficient method to collect firmly attached 197 benthic species, and these numbers probably underestimate the density of Urticina sp. in the 198 surveyed area. 


\subsection{Spawning}

Urticina sp. is gonochoric and iteroparous like U. felina (Mercier et al., 2011b), $U$.

201 fecunda (Larson et al., 2012), and U. crassicornis (Chia and Spaulding, 1972). Spawning of the

202 female was only directly witnessed once, starting on the evening of March 28, 2013 and

203 continuing until the next morning (Fig. 2A). Between 1000-1200 eggs were visually detected,

204 either floating around the spawner or already laying on the substrate. Transit time from the site

205 of release (mouth) to the substrate was up to 60 min under the study conditions. The male was

206 seen to release faint wisps of sperm over 1-2 h on the morning of March 29 (Fig. 2B), roughly

207 coinciding with the end of the female spawning. However, the eggs collected on the evening of

208 March $28(550-600 \mu \mathrm{m}$ in diameter) showed signs of development (elevation of the fertilization

209 envelope) supporting the possibility that the male had started spawning earlier, in synchrony with

210 the female (or even before), and that sperm release was too faint to be detected easily. It might be

211 continuous or sporadic over the long 12-h spawning period. In some species, the release of sperm

212 in the water column may trigger female spawning (Clark and Dewel, 1974; Nyholm, 1949;

213 Siebert, 1974). In contrast, the deep-sea epibiotic sea anemone Allantactis parasitica living in

214 association with deep-sea gastropods releases gametes in brief mass events, coincident with the

215 breeding aggregations exhibited by its host (Mercier and Hamel, 2009a). Should a protracted

216 gamete release at the individual level be confirmed in Urticina sp., it might offset the constraints

217 of a sedentary lifestyle and relatively low densities, potentially maximizing fertilization success.

218 Combined with negative oocyte buoyancy (see below for details), which would favour philopatry

219 and the maintenance of reproductive densities, this spawning strategy could explain the success

220 of this species in bathyal habitats of the Northwest Atlantic. Other adaptations suspected to

221 favour fertilization across distant benthic conspecifics in deep-sea invertebrates include longer 
222 spermatozoa mobility and competency, and retention of gametes close to the adults until

223 fertilization in echinoids (Young 1994), as well as in the deep-sea coral Flabellum angulare

224 (Mercier et al., 2011a).

225 Both the male and female of Urticina sp. released gametes through the mouth (Fig. 2A,

226 b) while the column and tentacles were fully extended. The upper section of the gastrovascular

227 cavity of the female was slightly visible during spawning (Fig. 2A) whereas the male oral cavity

228 was forming a protruding conical shape (Fig. 2B). Newly-released sperm dispersed rapidly in

229 the water column and oocytes initially floated in mid-water, about 10-12 cm from the bottom.

230 Eventually (inside $1 \mathrm{~h}$ ), the oocytes (or fertilized eggs) sank to layer the rock on which the

231 female was attached and its immediate vicinity (Fig. 2C). Shick and Lamb (1977) described

232 broadcasted oocytes that remained attached by mucus close to the base of the female in

233 Diadumene leucolena along the Atlantic coast of North America. In Urticina sp., no oocytes

234 were seen to adhere to the spawning female, and no mucus was apparent. None of the gametes

235 were ingested, even though the tentacles were deployed and prey of similar sizes had previously

236 been accepted by the same individual (e.g. copepods).

237 Urticina sp. spawned at the end of March, a period when most shallow-water species of

238 benthic marine invertebrates reproduce along the eastern coast of Canada (Mercier and Hamel,

239 2010). This period coincided with a major increase in phytoplankton and zooplankton as well as

240 slight increase in bottom temperature, including in deep waters (DFO, 2009). Spawning and

241 larval release by many deep-sea cnidarians from the same geographic area are reportedly cued by

242 phytodetritus (in press; Baillon et al., 2014; Mercier and Hamel, 2009a, 2011; Sun et al., 2010;

243 Sun et al., 2011), and the coincident temperature cycle. Deposition of surface-derived particles at

244 depth has been suggested to trigger lipogenesis during late gametogenesis in Paracalliactis 
stephensoni (Van Praët and Duchateau, 1984), further supporting the role of marine snow in the

246 reproductive cycle of deep-water sea anemones.

\subsection{Development}

Broadcasted oocytes were $\sim 550-600 \mu \mathrm{m}$ in diameter, orange in color, and negatively buoyant. Non-brooded negatively buoyant lecithotrophic oocytes are very rare and, as far as we

250 know, have never before been reported in any sea anemone or deep-sea invertebrate before

251 except perhaps in the deep-sea scleractian coral Flabellum angulare (Mercier et al., 2011a). Eggs

252 that are released in the water column may exhibit different properties, in part through

253 manipulation of their biochemical composition, as seen in sea stars that produce eggs of similar

254 volumes but different buoyancies by altering the total amount of lipid present while leaving the

255 protein levels unchanged (Prowse et al., 2008). Negative buoyancy of pelagic eggs likely favours

256 recruitment in the natal habitat (philopatry), similar to brooding strategies, and could partly

257 explain the patchy distribution of Urticina sp. in deep waters of the western Atlantic. All other

258 deep-sea free-spawning lecithotrophic marine invertebrates from the same geographic area,

259 including corals, echinoderms, and other sea anemones release pelagic oocytes that are positively

260 buoyant (Mercier and Hamel, 2009b, a).

261 At the time of spawning and in the subsequent few hours, only the elevation of the

262 fertilization envelope was visible, but there was no sign of early division (Fig. 3A). The first

263 confirmed cleavages were at the 16-32-cell stage and occurred within $12 \mathrm{~h}$ (Fig. 3B), consistent

264 with reports of meroblastic cleavage in U. crassicornis (Chia and Spaulding, 1972). Round

265 blastulae emerged 2-3 days post spawning; these blastulae have poorly defined blastomeres, as

266 also observed by Chia and Spaulding (1972). After about 4 days, the embryos reached the early

267 gastrula stage (Fig. 3C, D). The formation of a yolk plug (Fig. 3E) occurred after 5-6 days. Chia 
and Spaulding (1972) suggested that this yolk plug was formed by a process of epiboly. After 7-

2698 days, the yolk plug disappeared and the fully-developed gastrulae became slightly elongated

270 with a visible blastopore (Fig. 3F). Early planulae appeared 8-15 days post spawning, and fully-

271 developed elongated planulae after 17-21 days (Table 1, Fig. 3G). Both stages moved quickly

272 but remained close to the substrate. No pelagic phase was ever noted in Urticina sp. A few

273 planulae with visible tentacles buds (Fig. 3H, I) were observed to temporally attach to hard

274 substrates between days 22-24. Metamorphosis to the polyp shape (Fig. 3J, K, L) occurred 30-35

275 days post spawning. The septum were then clearly visible along the transparent body wall (Fig.

$2763 \mathrm{~K}, \mathrm{~L})$.

277 Planulae settled close to each other (sometimes side by side) and occurred preferentially

278 on rocks, generally on undersurfaces or inside crevasses. Some planulae were able to settle on

279 artificial substrates (e.g. glass, plastic), but after a delay of 1-2 weeks relative to settlement on

280 rocks. In addition, whenever planulae first settled on these sub-optimum substrates, they quickly

281 relocated to rocks (inside a few hours) that were added a posteriori. It has been proposed that

282 planulae of certain sea anemones, including Urticina crassicornis, may use a diffuse ectodermal

283 sensory network to select a substrate for settlement (Shick, 1991). Moreover, post-settlement

284 relocation to an optimal substrate has previously described in the temperate intertidal species $A$.

285 elegantissima and A. xanthogrammica (Sebens, 1982).

\subsection{Growth}

Metamorphosis into the juvenile (polyp) was completed as the general body shape of the

288 planulae flattened and the pedal disk enlarged (Fig. 3K, L; Fig. 4A) followed by the appearance

289 of the first 8 tentacles (Fig 4B). At that stage, the juveniles of Urticina sp. were still not able to

290 feed. After 5 months, the 8 tentacles elongated (Fig. 4C) and the mouth opened enabling feeding 
291 in the juveniles which had reached $\sim 1000 \mu$ m pedal disk diameter. Some individuals were 292 observed to prey on copepods. The number of tentacles and the overall size of the juveniles 293 increased over time to reach a maximum of $16 \mathrm{~mm}$ pedal disk diameter and 54 tentacles after 2.5

294 years (Table 1, Fig. 4). The juveniles are still growing in the mesocosm to this day.

The best curve fit between empirical data and the known adult size was obtained with

296 exponential growth $\left(\mathrm{R}^{2}=0.926, \mathrm{p}<0.001\right)$ : $\mathrm{S}_{\mathrm{t}}=\mathrm{e}^{\text {at }}$ where $S_{t}$ is the size reached after a certain time

$297 t$ based on a growth constant $a$ estimated from the first 2.5 years of basal disk increments

298 measured in the present study (Fig. 5). Exponential growth models are not uncommon in sea

299 anemones (Balamurugan et al., 2014) and other animals (Sebens, 1987). The extrapolation

300 revealed that growth to $90 \mathrm{~mm}$ in Urticina sp., which corresponds to the adult size measured

301 here, would require $\sim 4$ years. Comparatively, the smaller sea anemone Allantactis parasitica

302 ( $\sim 35 \mathrm{~mm}$ pedal disk diameter) from the same geographic area and depth was estimated to require

303 6-7 years to reach full adult size (Mercier and Hamel, 2009a). To our knowledge, Urticina sp.

304 represents only the second actiniarian species from the deep for which growth data are available.

305 While valuable, growth rates measured in mesocosms remain approximations, as conditions in

306 the laboratory do not perfectly mimic conditions occurring in situ (e.g. pressure and food 307 quantity/quality).

308 Despite intensive bottom fisheries on the eastern coast of Canada (http://www.dfo309 mpo.gc.ca/Library/334918.pdf), great biomasses of Urticina sp. and other large sea anemones 310 continue to be recorded as bycatch of research surveys conducted along the continental slope of

311 Newfoundland (DFO, unpublished data). The fact that most trawl-caught specimens observed

312 during the research surveys were damaged (torn from the substrate) implies that trawl fisheries

313 inflict significant damage to deep anemone communities. Nevertheless, the resilience of deep- 
314 water sea anemones inferred by their prolonged survival in captivity, combined with the

315 reproductive strategy determined here for Urticina sp., apparently contribute to offset

316 disturbances to localised populations. However, if fishing pressure increases over the years to

317 come, this scenario could change rapidly given the slow growth rate, limited fecundity and

318 breeding periodicity of Urticina sp.

\section{Acknowledgments}

We are grateful to the scientific staff of Fisheries and Oceans Canada and the Canadian

321 Coast Guard for assisting us with the collections aboard of the CCGS Teleost and two

322 anonymous reviewers for helping us improve an earlier version of this manuscript. This research

323 was partly funded by grants from the Natural Sciences and Engineering Research Council of

324 Canada (NSERC; Grant no. 311406) and the Canada Foundation for Innovation (CFI; Grant no.

32511231 ) to A. Mercier and by grants from the US National Science Foundation (DEB-1257796) to

326 M. Daly.

\section{References}

328 Aldred, R.G., Riemann-Zurneck, K., Thiel, H., Rice, A.L., 1979. Ecological observations on the 329 deep-sea anemone Actinoscyphia aurelia. Oceanol. Acta 2, 389-395.

330 Andrews, A.H., Cordes, E.E., Mahoney, M.M., Munk, K., Coale, K.H., Cailliet, G.M., Heifetz, 331 J., 2002. Age, growth and radiometric age validation of a deep-sea, habitat-forming gorgonian 332 (Primnoa resedaeformis) from the Gulf of Alaska. Hydrobiologia 471 (1), 101-110.

333 Appellöf, J.J.A., 1900. Studien über Actinien-Entwicklung. Bergens Museums Aabog 1, 3-99. 
334 Baillon, S., Hamel, J.-F., Mercier, A., in press. Protracted oogenesis and annual reproductive 335 periodicity in the deep-sea pennatulacean Halipteris finmarchica (Anthozoa, Octocorallia). Mar. 336 Ecol.

337 Baillon, S., Hamel, J.-F., Wareham, V.E., Mercier, A., 2012. Deep cold-water corals as nurseries 338 for fish larvae. Front. Ecol. Environ. 10 (7), 351-356.

339 Baillon, S., Hamel, J.-F., Wareham, V.E., Mercier, A., 2014. Seasonality in reproduction of the 340 deep-water pennatulacean coral Anthoptilum grandiflorum. Mar. Biol. 161, 29-43.

341 Balamurugan, J., Kumar, T.T.A., Ghosh, S., 2014. Expansion behavior, growth and survival of 342 the sea anemone Stichodactyla haddoni (Saville-Kent, 1893) with anemonefishes in captivity. 343 Invertebrate Zoology 11 (2), 315-324.

344 Bronsdon, S.K., Tyler, P.A., Rice, A.L., Gage, J.D., 1993. Reproductive biology of two epizoic 345 anemones from the deep north-eastern Atlantic Ocean. J. Mar. Biol. Assoc. U. K. 73 (3), 531 346542.

347 Brooke, S., Young, C.M., 2009. In situ measurement of survival and growth of Lophelia pertusa 348 in the northern Gulf of Mexico. Mar. Ecol. Prog. Ser. 397, 153-161.

349 Buhl-Mortensen, L., Mortensen, P.B., 2005. Distribution and diversity of species associated with 350 deep-sea gorgonian corals off Atlantic Canada. In: Freiwald, A., Roberts, J.M. (Eds.), Cold351 Water corals and ecosystems. Springer Verlag, Berlin, pp. 849-879.

352 Cairns, S.D., 1982. Antarctic and Subantarctic Scleractinia. Biology of the Antarctic Seas XI. 353 Antarct. Res. Ser. 34, 1-74.

354 Cairns, S.D., 2007. Deep-water corals: an overview with special reference to diversity and 355 distribution of deep-water scleractinian corals. Bull. Mar. Sci. 81 (3), 311-322. 
356 Cerrano, C., Danovaro, R., Gambi, C., Pusceddu, A., Riva, A., Schiaparelli, S., 2010. Gold coral 357 (Savalia savaglia) and gorgonian forests enhance benthic biodiversity and ecosystem functioning 358 in the mesophotic zone. Biodivers. Conserv. 19 (1), 153-167-167.

359 Chia, F.-S., Spaulding, J.G., 1972. Development and juvenile growth of the sea anemone, Tealia 360 crassicornis. Biol. Bull. (Woods Hole) 142 (2), 206-218.

361 Clark, W.H., Dewel, W.C., 1974. The structure of the gonads, gametogenesis, and sperm-egg 362 interactions in the Anthozoa. Am. Zool. 14 (2), 495-510.

363 Cordes, E.E., Nybakken, J.W., VanDykhuizen, G., 2001. Reproduction and growth of 364 Anthomastus ritteri (Octocorallia: Alcyonacea) from Monterey Bay, California, USA. Mar. Biol. $365138(3), 491-501$.

366 Daly, M., Chaudhuri, A., Gusmão, L., Rodríguez, E., 2008. Phylogenetic relationships among 367 sea anemones (Cnidaria: Anthozoa: Actiniaria). Mol. Phylogenet. Evol. 48 (1), 292-301.

368 DFO, 2009. 2008 State of the ocean: Physical oceanographic conditions in the Newfoundland 369 and Labrador region DFO. Can. Sci. Advis. Sec. Sci. Advis. Rep. 2009/057.

370 Fautin, D.G., Daly, M., Cappola, V.A., 2005. Sea anemones (Cnidaria: Actiniaria) of the Faroe 371 Islands: a preliminary list and biogeographic context. Annales Societatis Scientiarum Færoensis 372 Supplementum 41, 77-87.

373 Gage, J.D., Tyler, P.A., 1991. Deep-sea biology: a natural history of organisms at the deep-sea 374 floor. Cambridge University Press, Cambridge.

375 Hamel, J.-F., Sun, Z., Mercier, A., 2010. Influence of size and seasonal factors on the growth of 376 the deep-sea coral Flabellum alabastrum in mesocosm. Coral Reefs 29, 521-525.

377 Hand, C.H., 1955. The sea anemones of central California. Part II. The endomyarian and 378 mesomyarian anemones. Wasmann J. Biol. 13, 37-99. 
379 Hauswaldt, J.S., 1999. Urticina Mcpeaki, A New Species Of Sea Anemone (Anthozoa:

380 Actiniaria: Actiniidae) From. Proc. Biol. Soc. Wash. 112, 652-660.

381 Kaliszewicz, A., Panteleeva, N., Olejniczak, I., Boniecki, P., Sawicki, M., 2012. Internal

382 brooding affects the spatial structure of intertidal sea anemones in the Arctic-boreal region. Polar 383 Biol. 35 (12), 1911-1919.

384 Katoh, K., Misawa, K., Kuma, K.i., Miyata, T., 2002. MAFFT: a novel method for rapid 385 multiple sequence alignment based on fast Fourier transform. Nucleic Acids Res. 30 (14), 30593863066.

387 Kearse, M., Moir, R., Wilson, A., Stones-Havas, S., Cheung, M., Sturrock, S., Buxton, S., 388 Cooper, A., Markowitz, S., Duran, C., 2012. Geneious Basic: an integrated and extendable 389 desktop software platform for the organization and analysis of sequence data. Bioinformatics 28 390 (12), 1647-1649.

391 Larson, P.G., Hamel, J.-F., Mercier, A., 2012. Redescription and notes on the reproductive 392 biology of the sea anemone Urticina fecunda (Verrill, 1899), comb. nov. (Cnidaria: Actiniaria: 393 Actiniidae). Zootaxa 3523, 69-79.

394 Mercier, A., Hamel, J.-F., 2009a. Reproductive periodicity and host-specific settlement and 395 growth of a deep-water symbiotic sea anemone. Can. J. Zool. 87 (11), 967-980.

396 Mercier, A., Hamel, J.-F., 2009b. Endogenous and exogenous control of gametogenesis and 397 spawning in echinoderms. Adv. Mar. Biol. 55, 1-302.

398 Mercier, A., Hamel, J.-F., 2010. Synchronized breeding events in sympatric marine 399 invertebrates: role of behavior and fine temporal windows in maintaining reproductive isolation. 400 Behav. Ecol. Sociobiol. 64, 1749-1765. 
401 Mercier, A., Hamel, J.-F., 2011. Contrasting reproductive strategies in three deep-sea octocorals 402 from eastern Canada: Primnoa resedaeformis, Keratoisis ornata and Anthomastus grandiflorus. 403 Coral Reefs 30, 337-350.

404 Mercier, A., Sun, Z., Hamel, J.-F., 2011a. Reproductive periodicity, spawning and development 405 of the deep-sea scleractinian coral Flabellum angulare. Mar. Biol. 158, 371-380.

406 Mercier, A., Sun, Z., Hamel, J.-F., 2011b. Internal brooding favours pre-metamorphic chimerism 407 in a non-colonial cnidarian, the sea anemone Urticina felina. Proc. R. Soc. B. 278, 3517-3522.

408 Mortensen, P.B., Rapp, H.T., 1998. Oxygen and carbon isotope ratios related to growth line 409 patterns in skeletons of Lophelia pertusa (L) (Anthozoa, Scleractinia): Implications for 410 determination of linear extension rates. Sarsia 83 (5), 433-446.

411 Muirhead, A., Tyler, P.A., Thurston, M.H., 1986. Reproductive biology and growth of the genus 412 Epizoanthus (Zoanthidea) from the north-east Atlantic. J. Mar. Biol. Assoc. U. K. 66 (1), 131413143.

414 Nyholm, K.G., 1949. On the development and dispersal of Athenaria actinia with special 415 reference to Halcampa duodecimcirrata, M. Sars. Zool. Bidrag. Uppsala 27, 465-505.

416 Orejas, C., Ferrier-Pagès, C., Reynaud, S., Gori, A., Beraud, E., Tsounis, G., Allemand, D., Gili, 417 J.M., 2011. Long-term growth rates of four Mediterranean cold-water coral species maintained in 418 aquaria. Mar. Ecol. Prog. Ser. 429, 57-65.

419 Prowse, T., Sewell, M., Byrne, M., 2008. Fuels for development: evolution of maternal 420 provisioning in asterinid sea stars. Mar. Biol. 153 (3), 337-349.

421 Risk, M.J., Heikoop, J.M., Snow, M.G., Beukens, R., 2002. Lifespans and growth patterns of two 422 deep-sea corals: Primnoa resedaeformis and Desmophyllum cristagalli. Hydrobiologia 471 (1 423 3), 125-131. 
424 Roark, E.B., Guilderson, T.P., Dunbar, R.B., Fallon, S.J., Mucciarone, D.A., 2009. Extreme

425 longevity in proteinaceous deep-sea corals. Proc. Natl. Acad. Sci. U. S. A. 106 (13), 5204-5208.

426 Roberts, J.M., Wheeler, A.J., Freiwald, A., 2006. Reefs of the deep: the biology and geology of 427 cold-water coral ecosystems. Science 312 (5773), 543-547.

428 Rodríguez, E., Daly, M., 2010. Phylogenetic relationships among deep-sea and chemosynthetic 429 sea anemones: Actinoscyphiidae and Actinostolidae (Actiniaria: Mesomyaria). PLoS ONE 5 (6), $430 \mathrm{e} 10958$.

431 Rodríguez, E., Orejas, C., López-González, P.J., Gili, J.M., 2013. Reproduction in the externally 432 brooding sea anemone Epiactis georgiana in the Antarctic Peninsula and the Weddell Sea. Mar. 433 Biol. 160 (1), 67-80.

434 Rodríguez, E., Barbeitos, M.S., Brugler, M.R., Crowley, L.M., Grajales, A., Gusmão, L., 435 Häussermann, V., Reft, A., Daly, M., 2014. Hidden among sea anemones: the first 436 comprehensive phylogenetic reconstruction of the order Actiniaria (Cnidaria, Anthozoa, 437 Hexacorallia) reveals a novel group of hexacorals. PloS One 9, e96998.

438 Rogers, A.D., 2009. Cnidarians (Cnidaria). The Timetree of Life, Oxford University Press, USA, $439 \quad 233-238$.

440 Sanamyan, N.P., Sanamyan, K.E., 2006. The genera Urticina and Cribrinopsis (Anthozoa: 441 Actiniaria) from the north-western Pacific. J. Nat. Hist. 40 (7-8), 359-393.

442 Sebens, K.P., 1982. Recruitment and habitat selection in the intertidal sea anemones, 443 Anthopleura elegantissima (Brandt) and A. xanthogrammica (Brandt). J. Exp. Mar. Biol. Ecol. $444 \quad 59(2), 103-124$.

445 Sebens, K.P., 1987. The ecology of indeterminate growth in animals. Annu. Rev. Ecol. Syst. 18, $446 \quad 371-407$. 
447 Sherwood, O.A., Edinger, E.N., 2009. Ages and growth rates of some deep-sea gorgonian and 448 antipatharian corals of Newfoundland and Labrador. Can. J. Fish. Aquat. Sci. 66 (1), 142-152.

449 Shick, J.M., 1991. A functional biology of sea anemones. Chapman and Hall, London.

450 Shick, J.M., Lamb, A.N., 1977. Asexual reproduction and genetic population structure in the 451 colonizing sea anemone Haliplanella luciae. Biol. Bull. 153 (3), 604-617.

452 Siebert, A.E., 1974. A description of the embryology, larval development, and feeding of the sea 453 anemones Anthopleura elegantissima and A. xanthogrammica. Can. J. Zool. 52 (11), 1383-1388.

454 Solé-Cava, A.M., Thorpe, J.P., Kaye, J.G., 1985. Reproductive isolation with little genetic 455 divergence between Urticina (=Tealia) felina and U. eques (Anthozoa: Actiniaria). Mar. Biol. 85 456 (3), 279-284.

457 Solé-Cava, A.M., Thorpe, J.P., Todd, C.D., 1994. High genetic similarity between 458 geographically distant populations in a sea anemone with low dispersal capabilities. J. Mar. Biol. 459 Assoc. U. K. 74 (04), 895-902.

460 Stamatakis, A., 2006. RAxML-VI-HPC: maximum likelihood-based phylogenetic analyses with 461 thousands of taxa and mixed models. Bioinformatics 22 (21), 2688-2690.

462 Sun, Z., Hamel, J.-F., Mercier, A., 2011. Planulation, larval biology, and early growth of the 463 deep-sea soft corals Gersemia fruticosa and Duva florida (Octocorallia: Alcyonacea). Invertebr. 464 Biol. 130 (2), 91-99.

465 Sun, Z., Hamel, J.-F., Mercier, A., 2012. Marked shifts in offspring size elicited by frequent 466 fusion among siblings in an internally brooding marine invertebrate. Am. Nat. 180 (5), E151467 E160.

468 Sun, Z., Hamel, J.-F., Edinger, E., Mercier, A., 2010. Reproductive biology of the deep-sea 469 octocoral Drifa glomerata in the Northwest Atlantic. Mar. Biol. 157, 863-873. 
470 Van Praët, M., 1990. Gametogenesis and the reproductive cycle in the deep-sea anemone

471 Paracalliactis stephensoni (Cnidaria: Actiniaria). J. Mar. Biol. Assoc. U. K. 70 (1), 163-172.

472 Van Praët, M., Duchateau, G., 1984. Mise en évidence chez une Actinie abyssale (Paracalliactis

473 stephensoni) d'un cycle saisonnier de reproduction. C. R. Acad. Sci. Serie III Sci. Vie 299 (17),

$474 \quad 687-690$.

475 Van Praët, M., Rice, A.L., Thurston, M.H., 1990. Reproduction in two deep-sea anemones

476 (Actiniaria); Phelliactis hertwigi and P. robusta. Prog. Oceanogr. 24 (1), 207-222.

477 Watling, L., France, S.C., Pante, E., Simpson, A., 2011. Biology of deep-water octocorals. Adv. 478 Mar. Biol. 60, 41-122.

479 Wedi, S.E., Fautin Dunn, D., 1983. Gametogenesis and reproductive periodicity of the subtidal 480 sea anemone Urticina lofotensis (Coelenterata: Actiniaria) in California. Biol. Bull. 165 (2), 458481472.

482 Young, C.M., 2003. Reproduction, development and life-history traits. In: Tyler, P.A. (Ed.), 483 Ecosystems of the deep oceans. Vol. 28. Ecosystems of the world. Elsevier, Amsterdam, 484 Netherlands, pp. 381-426. 
Table 1. Development kinetic and propagule size of Urticina sp. from April 2013 to April 2015

489 at a temperature ranging from -1 to $8^{\circ} \mathrm{C}$. A new stage was considered attained when $\sim 50 \%$ of

490 propagules reached it.

\begin{tabular}{|c|c|c|c|}
\hline Stage & Time & Size & Image \\
\hline Newly released oocytes & 0 & $550-600 \mu \mathrm{m}$ (diameter) & Fig. 3A \\
\hline 16 to 32 cells & $6-12 \mathrm{~h}$ & $600 \mu \mathrm{m}$ (diameter) & Fig. 3B \\
\hline Blastula & $2-3 d$ & $620-650 \mu \mathrm{m}$ (diameter) & \\
\hline Early gastrula & $4 d$ & $630-650 \mu \mathrm{m}$ (diameter) & Fig. 3C, D \\
\hline Gastrula (yolk plug) & $5-6 d$ & $630 \mu \mathrm{m}$ (length) & Fig. 3E \\
\hline Gastrula (fully formed) & $7-8 d$ & $670 \mu \mathrm{m}$ (length) & Fig. 3F \\
\hline Early planula & $8-15 d$ & $690 \mu \mathrm{m}$ (length) & \\
\hline Late planula & $17-21 \mathrm{~d}$ & $710 \mu \mathrm{m}$ (length) & Fig. 3G \\
\hline $\begin{array}{l}\text { Planula (appearance of tentacle } \\
\text { buds) }\end{array}$ & $22-24 d$ & $710 \mu \mathrm{m}$ (length) & Fig. $3 \mathrm{H}, \mathrm{I}$ \\
\hline $\begin{array}{l}\text { Metamorphosis and settlement } \\
\text { (cone-shaped body with septa) }\end{array}$ & $30-35 d$ & $900 \mu \mathrm{m}$ (diameter) & $\begin{array}{l}\text { Fig. 3J, K, } \\
\text { L; Fig. 4A }\end{array}$ \\
\hline 8 tentacles (non-feeding) & $5 \mathrm{mo}$ & $950 \mu \mathrm{m}$ (pedal disk) & Fig. 4B \\
\hline 8 tentacles (feeding) & $5 \mathrm{mo}$ & $1000 \mu \mathrm{m}$ (pedal disk) & Fig. 4C \\
\hline 12 tentacles & $5-6 \mathrm{mo}$ & $1100 \mu \mathrm{m}$ (pedal disk) & Fig. 4D, E \\
\hline 24 tentacles & $9-10 \mathrm{mo}$ & $1500 \mu \mathrm{m}$ (pedal disk) & Fig. 4F \\
\hline 24 tentacles & $12 \mathrm{mo}$ & 3-4 mm (pedal disk) & Fig. 4G \\
\hline 48 tentacles & $24 \mathrm{mo}$ & 9-11 mm (pedal disk) & Fig. $4 \mathrm{H}$ \\
\hline 54 tentacles & $30 \mathrm{mo}$ & 16 mm (pedal disk) & \\
\hline
\end{tabular}




\section{Figure Captions}

495 Fig. 1. Best tree from maximum likelihood analysis of the combined dataset of 12S, 16S, 18S, and 28S ribosomal genes. Arrow points to species under study. Bootstrap values greater than $75 \%$ are shown. See supplemental Table S1 for accession numbers of included

Fig. 2. (A) Spawning female Urticina sp. showing the broadcasted oocytes (arrows) and the mouth with part of the gastrovascular cavity slightly everted, (B) Male spawning with sperm broadcasted (arrow) through the cone-shaped mouth, (C) General view of the female with eggs laying on the rock and mud around it (arrows). Scale bars: in A $=35$ $\mathrm{mm}$; in $\mathrm{B}=20 \mathrm{~mm}$; in $\mathrm{C}=45 \mathrm{~mm}$.

Fig. 3. (A) Newly-released oocytes/zygotes, (B) Early embryos 16-32 cells, (C-D) Early gastrula, (E) Embryo with yolk plug (yp), (F) Fully-developed gastrula showing the blastopore (b), (G) Late planula, (H-I) Planula showing the appearance of the tentacle buds (tb), (J-L) Planula during metamorphosis into cone shape with visible septum (s) and mouth area (m). Detail on the kinetics are provided in Table 1. Scale bars: in A $=420 \mu \mathrm{m}$ (also applies to $\mathrm{B}$ and $\mathrm{D}$ ); in $\mathrm{C}=640 \mu \mathrm{m}$ (also applies to $\mathrm{E}-\mathrm{L}$ ).

Fig. 4. (A) Newly-settled Urticina sp. attached to the substrate, with septum and mouth clearly visible (B) Appearance of tentacles (t) in non-feeding propagule, (C) 8-tentacle feeding juvenile, (D-E) 12-tentacle juvenile, 5-6 month old, (F) 24-tentacle juvenile, 9-10 month old, (G) 24-tentacle juvenile with elongating tentacles, 1 year post spawning, $(\mathrm{H})$ 2-year old juvenile with 48 tentacles, measuring 9-11 mm pedal disk diameter. Detail on the 
kinetics are provided in Table 1. Scale bar in $\mathrm{A}=360 \mu \mathrm{m}$; in A-F; in $\mathrm{G}=1.5 \mathrm{~mm}$ and in $\mathrm{H}=4.5 \mathrm{~mm}$.

517 Fig. 5. Increment in basal disk diameter (mean \pm SD) in Urticina sp. measured over the initial 2.5 years (solid line) and extrapolated growth (dashed line) to maximum size $(90 \mathrm{~mm})$. Drop line/arrow shows time needed to reach the maximal size based on the extrapolated growth curve. 


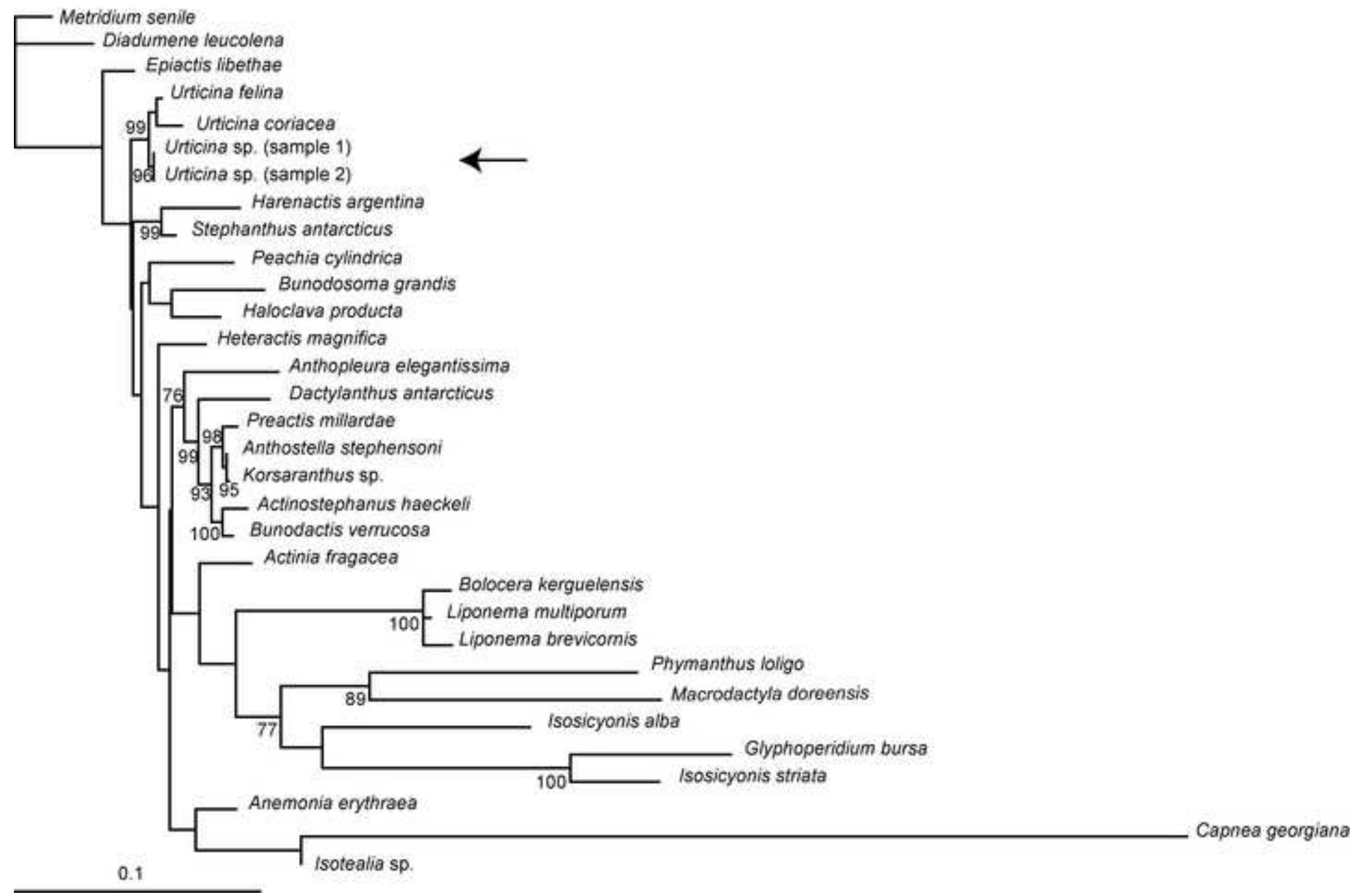


Figure 2
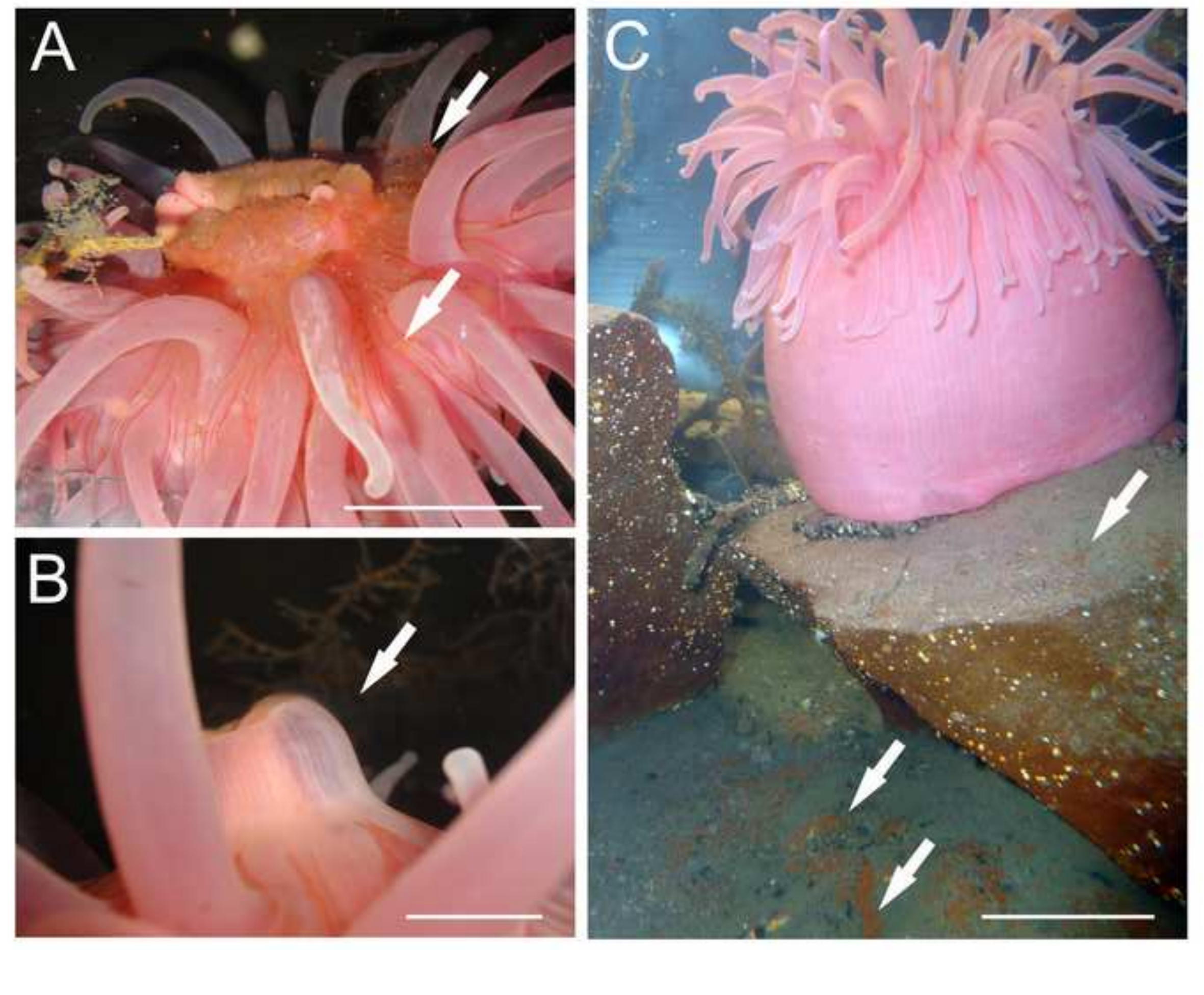

$\because \ldots$

$8 \%$. 350 -

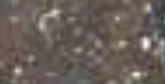

$$
\text { . }
$$
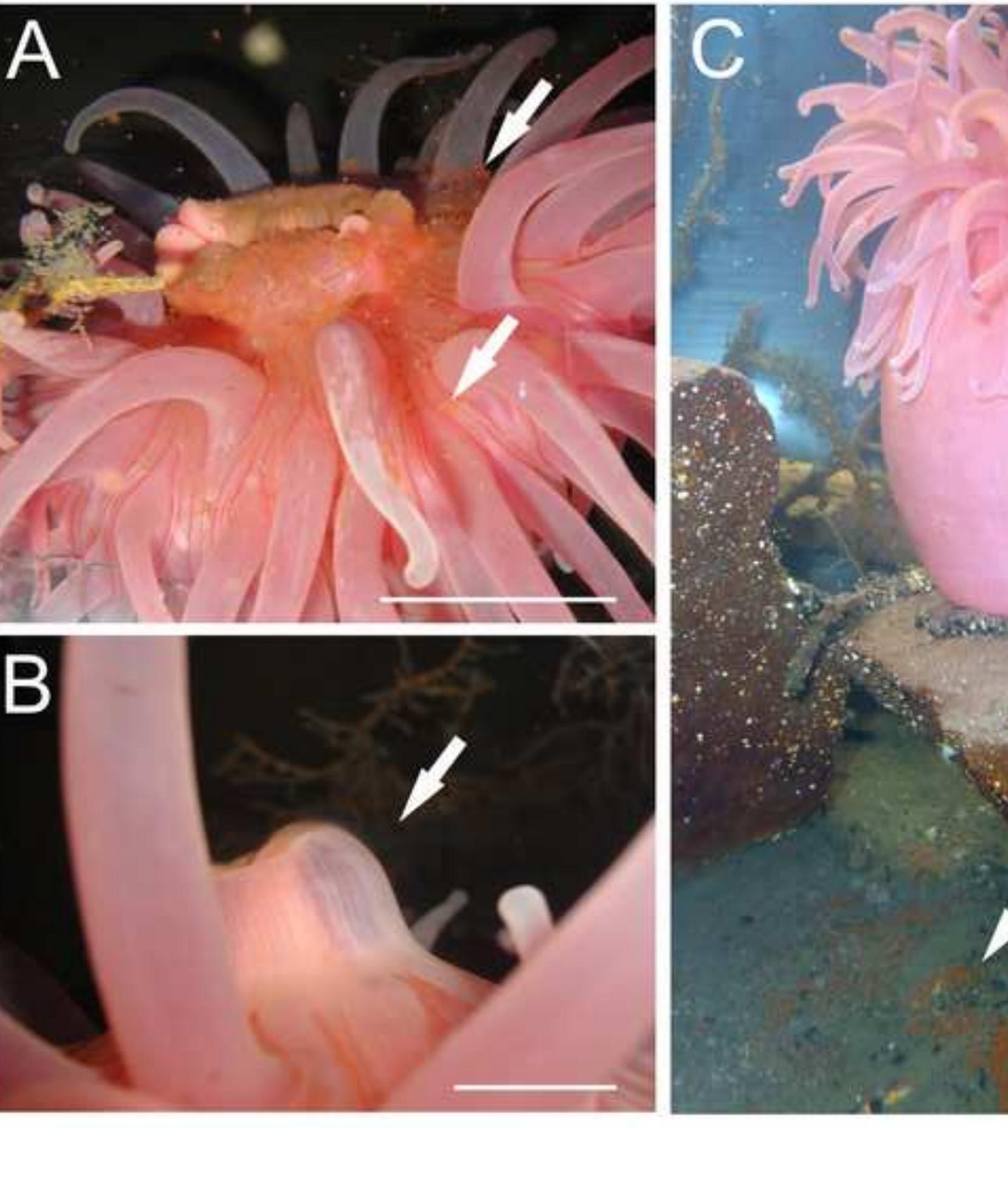

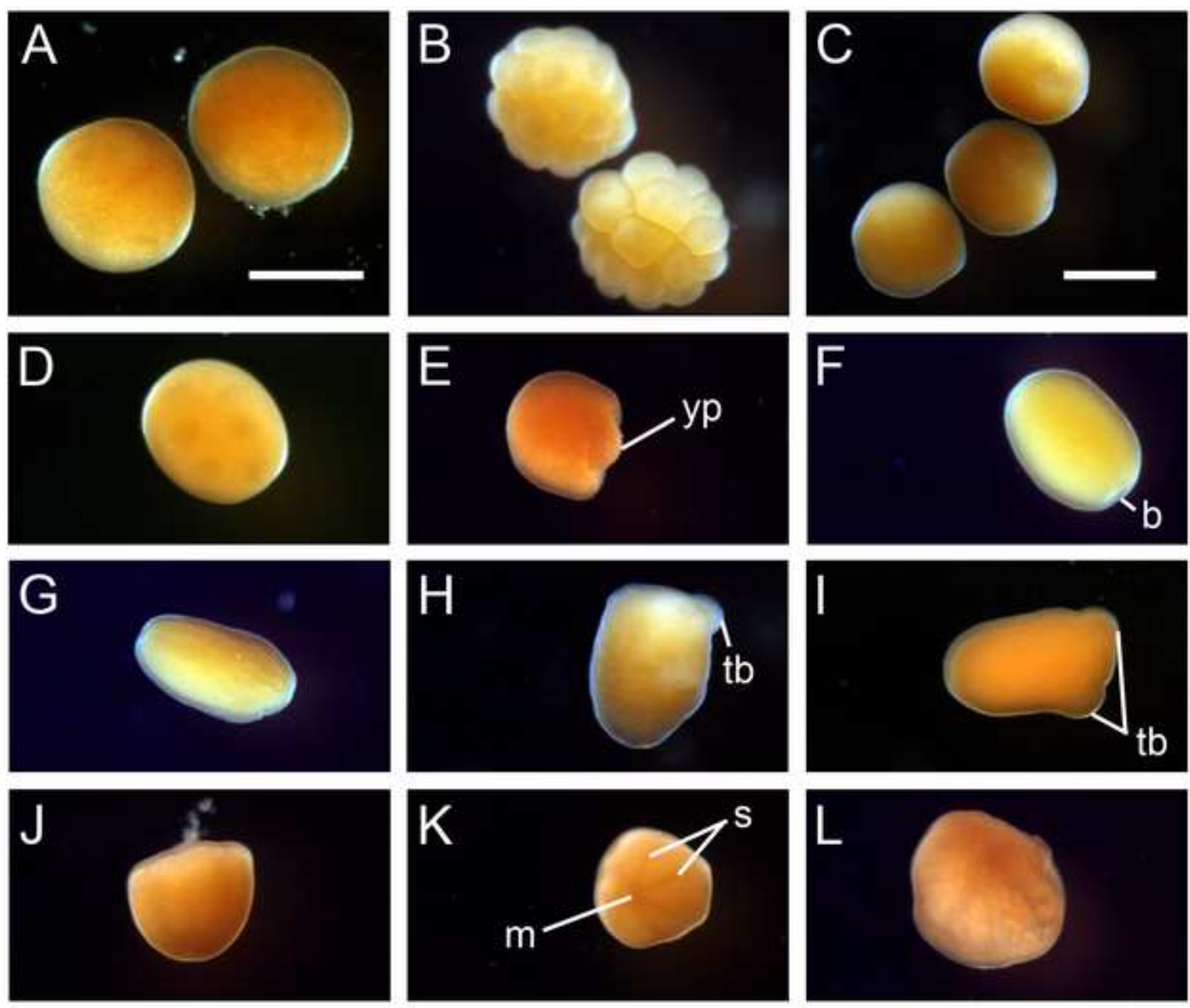
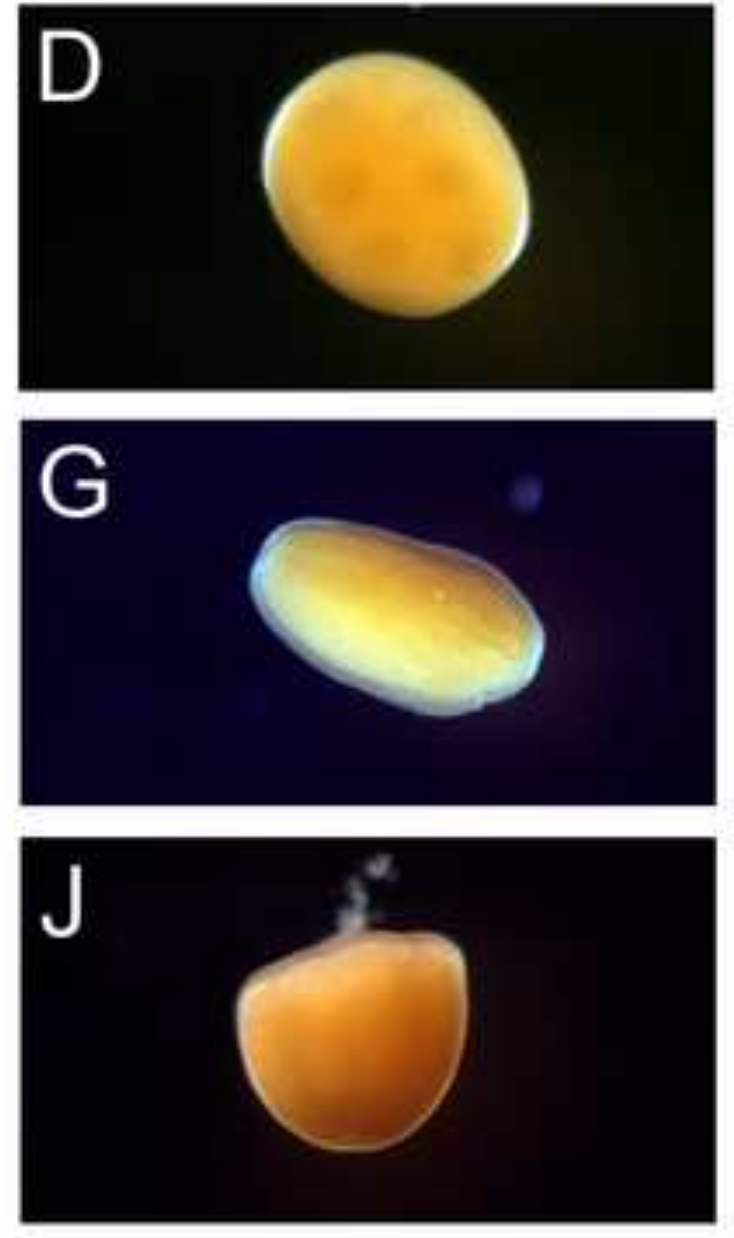

D

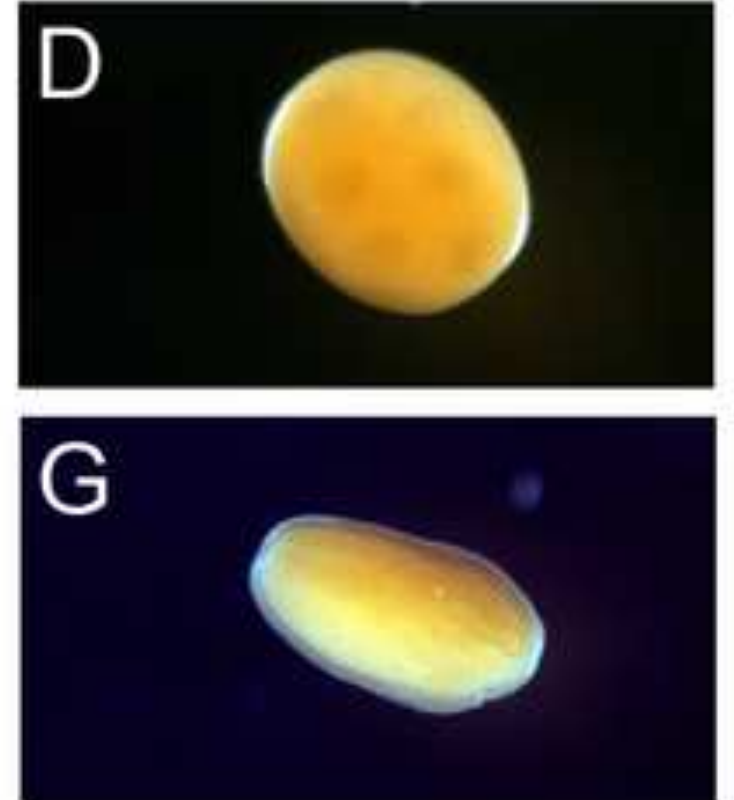

K $\mathrm{m}$ 

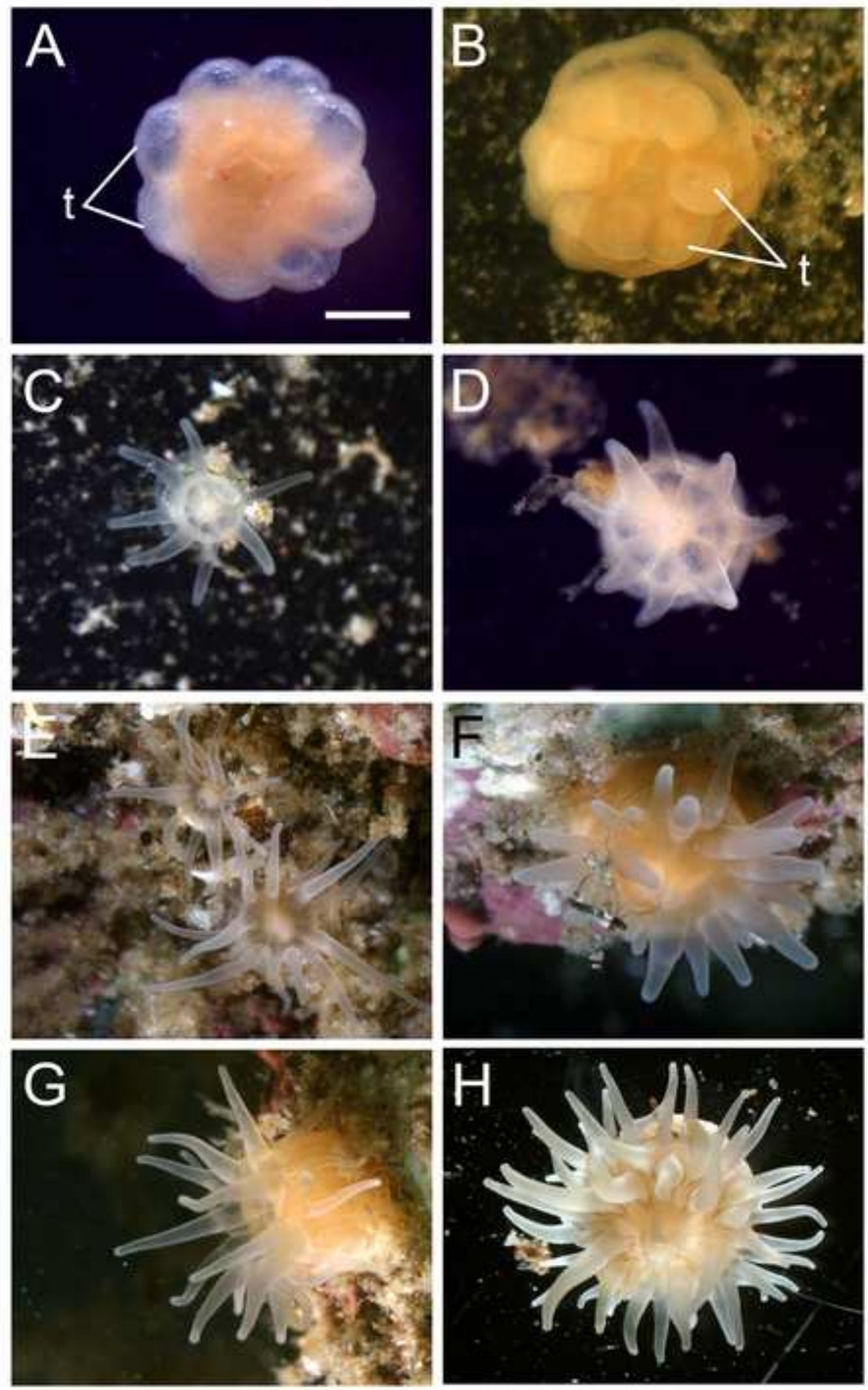


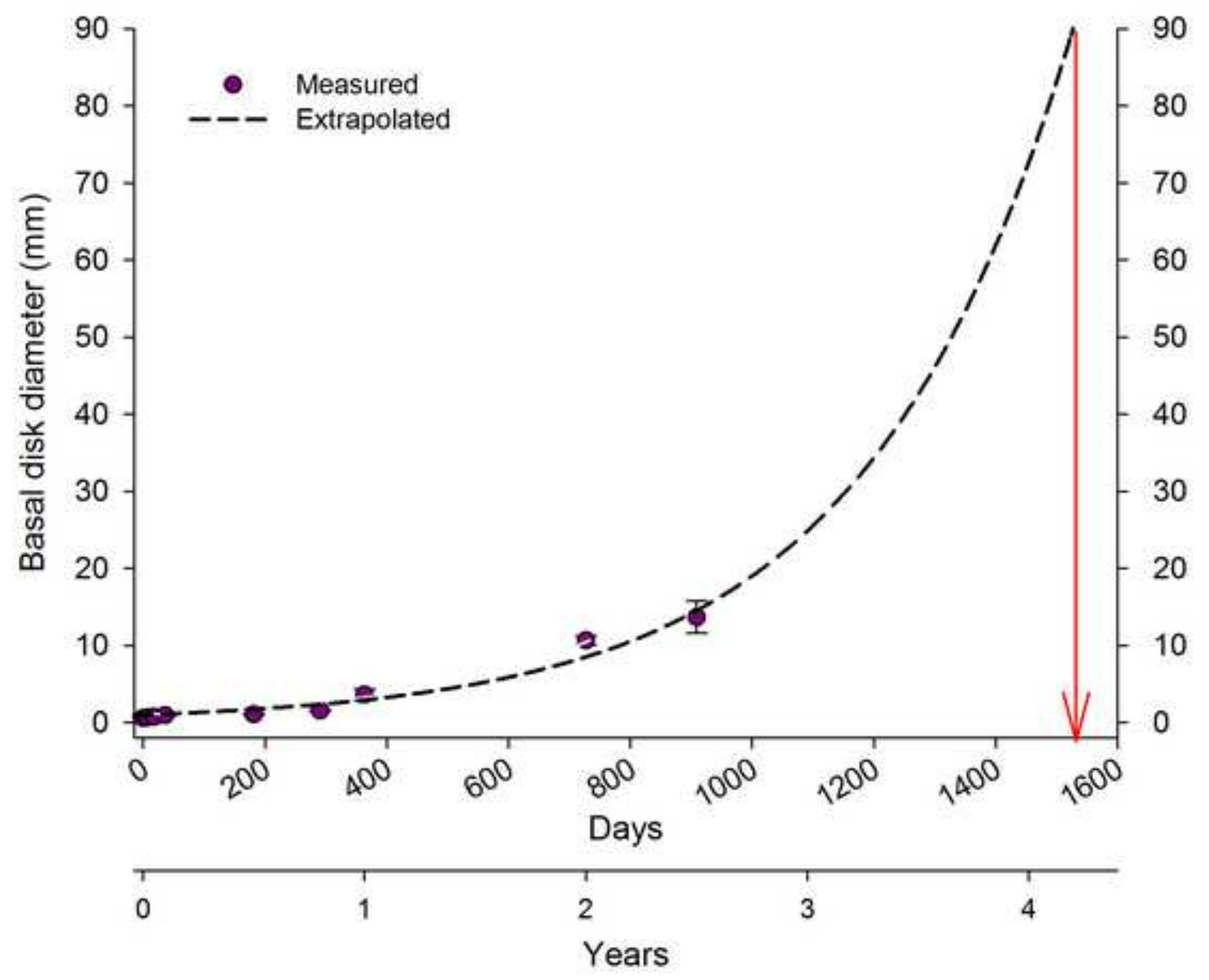

